\title{
ОСОБЛИВОСТІ ПРОГРАМ ВИКЛАДАННЯ МОРФОФУНКЦІОНАЛЬНИХ ДИСЦИПЛІН У ВИЩИХ НАВЧАЛЬНИХ ЗАКЛАДАХ І-ІІ РІВНІВ АКРЕДИТАЦІЇ В УКРАЇНІ Й ШВЕЙЦАРІЇ
}

\author{
Ю. Ф. Педанов, А. І. Гоженко, Р. Ф. Макулькін
}

Одеське обласне базове медичне училище,

Одеський національний медичний університет

\section{PECULIARITIES OF TEACHING SYLLABUSES IN MORPHOFUNCTIONAL DISCIPLINES AT HIGHER EDUCATIONAL ESTABLISHMENTS OF I-II ACCREDITATION LEVELS IN UKRAINE AND SWITZERLAND}

\author{
Yu. F. Pedanov, A. I. Hozhenko, R. F. Makulkin \\ Odessa Regional Basic Medical College, Odessa National Medical University
}

\begin{abstract}
У статті розглядаються особливості програм викладання дисциплін “Анатомія і фізіологія” та “Патологія” в Україні й Швейцарії.

Peculiarities of teaching syllabuses in Human Anatomy and Physiology and Pathology in Ukraine and Switzerland are reviewed in the article.
\end{abstract}

Вступ. Входження України в світовий освітній простір неможливебез соціально-економічних змін у суспільстві, без структурної реформи служби охорони здоров'я, що має відношення до всіх громадян держави.

Найважливішою складовою в системі є ефективна кадрова політика. Тільки забезпечення кваліфікованими медичними спеціалістами може допомогти досягненню кінцевої мети і забезпечити надання населенню якісної і ефективної допомоги.

Підготовка фахівців для галузі охорони здоров'я здійснюється у ВН3 I-IV рівнів акредитації МО3 України: серед них - 44 медичних училища, 69 медичних коледжів, два інститути медсестринства.

Контингент студентів ВНЗ I-II рівнів акредитації становить більш 70 тисяч осіб.

3 метою оптимального забезпечення молодшими медичними спеціалістами пріоритетним напрямком $€$ реформування вищої медичної освіти, комплексне вирішення методичних питань у ВНЗ I-II рівнів акредитації з урахуванням іноземного і збереження власного позитивного досвіду, оскільки цей етап також можна розглядати як етап підготовки до навчання у ВНЗ III-IV рівнів акредитації $[1,2,3]$.

Велику зацікавленість викликає дослідження системи навчання медичних сестер у Швейцарії, яка добре відома у світі своїми успіхами в системі охорони здоров'я.
Основна частина. В Європі не існує єдиної системи підготовки молодших медичних спеціалістів. В Швейцарії навчання медичних сестер відбувається спеціалізовано на ранніх етапах. Так, наприклад, програма вивчення морфофункціональних дисциплін для медичних сестер загального профілю в університетському госпіталі м. Берна передбачає: на засвоєння фундаментальної дисципліни “Анатомія і фізіологія”, яка вивчається на першому курсі (3-5 годин в тиждень) в розділі 1.4.1. “Основи біології” виділено загалом 124 години. В тому числі "Введення в основи біології" 38 годин: нервова система, шкіра, серцево-судинна система, дихальна система, кров і захисні системи організму, опорно-руховий апарат, ендокринна система, шлунково-кишковий тракт, органи виділення.

"Поглиблена робота" передбачає вивчення взаємодії органів у системах (кількість годин у дужках): нервова (11), серцево-судинна (11), травна, враховуючи біохімію і обмін речовин (14), кров (15), дихальна система (4), опорно-руховий апарат (11), сечова і статева (7), ендокринна (5), сенсорні органи - зір і слух (6), відвідування анатомічного інституту (2).

Всього 86 годин.

На 2 курсі навчання розглядаються питання "Патології” в тематичній області №5 - “Догляд за пацієнтами різних вікових груп”, розділи: 


\section{1. Активність і рухомість:}

захворювання опорно-руховогоапарату(6), неврологічні захворювання-інсульт, параліч тощо (6), неврологічна патологія (8), епілепсія (4), хірургічна іортопедична патологія у дітей (6), ревматизм (4), запаморочення (3), захворювання периферичної нервової системи (3), введення в науку про хвороби (6), опікова хвороба (3).

Всього 49 годин.

\section{2. Життєзабезпечення:}

захворювання дихальноїі серцево-судинноїсистем (15), хірургічні втручання при вроджених вадах серця (3), операції на серці (4), педіатрія - гемофілія та інші захворювання крові (3), дитячі інфекції(1), алергія і анафілактичний шок (2), туберкульоз, аспіраційна пневмонія, емфізема, легеневесерце, пневмоторакс, плеврит (3), поглиблене вивчення хвороб серця, включаючи фармакологію (3).

Всього 34 години.

3. Відпочинок $і$ сон: значення сну та його порушення (2).

4. Харчування $і$ обмін речовин:

симптоми хвороб - цукровий діабет, захворювання органів травлення, інфекційні (18), симптоми запальних захворювань кишечнику, щитоподібної залози (5), захворювання імунної системи ВІЛ, СНІД (3), педіатрія - патологія шлунково-кишкового тракту (3).

5. Дитячі хвороби:

інфекційні і щеплення (1), хвороби печінки і сечового міхура (6), алергія і анафілактичний шок (2), автоімунні захворювання (3), ендокринні хвороби (6).

Всього 18 годин.

6. Видільна система:

хвороби нирок і сечових шляхів (6), трансплантація нирок (4), урологічні захворювання дитячого віку (3).

Всього 13 годин.

\section{7. Вибрані теми догляду:}

порушення видільних функцій (2), фізіологія болю (6), догляд за гінекологічними хворими (6), вагітність, роди, післяпологовий період (15), психопатологічні симптоми (9), психічні хвороби - діагностика і терапія (9), деякі психічні хвороби (6).

Всього 53 години. Загалом 198 годин.

В школі медичних сестер психіатричного профілю (м. Мюнсинген) вивчається дисципліна "Анатомія і фізіологія з елементами патологіі” на першому курсі (кількість годин у дужках):

опорно-руховий апарат (14), серцево-судинна система (8), кров (6), дихальна система (8), нервова система (10), органи чуття (6), шкіра і терморегуляція (4), система органів травлення (10), сечова система (10), репродуктивна система (12), ендокринна система (12), імунна система (12).

Загалом 112 годин.
Навчання за програмою "Патофізіологія і патологія" здійснюється на 2 курсі (кількість годин у дужках) 3 тем: хвороби серця і судин. Шок (10), захворювання шкіри (2), хвороби органів чуття (4), патологія опорно-рухового апарату (6), нервові хвороби (10), захворювання системи органів дихання (4), хвороби шлунка, кишечнику, підшлункової залози (8), захворювання печінки і жовчного міхура (8), хвороби сечової і статевої систем (10), запалення, біль (8), виразкова хвороба (4), патологія обміну речовин (4), лабораторні показники і лабораторний аналіз (4).

Загалом 76 годин.

На фінальному етапі - екзамен.

Таке фрагментарне вивчення питань патології сумісно з клінічними дисциплінами, можливо, пов' язано 3 вузькою спеціалізацією на ранніх етапах навчання спеціалістів.

В цілому, це відповідає концепції про права ВНЗ самостійно вирішувати питання щодо формування програм, навчальних планів і порядок викладання дисциплін.

На наш погляд, у ВНЗ I-II рівнів акредитації в Україні більш доцільно викладати інтегровану дисципліну “Анатомія і фізіологія людини" за запропонованим нами навчальним планом (зі збереженням загальної кількості годин), де взаємопов'язані питання структури і функції, нейрогуморальної регуляції усіх систем і організму в цілому. Так само це стосується програм і навчальних планів 3 дисциплін "Патоморфологія" і "Патофізіологія", які можна викладати в одній дисципліні “Патологія людини” $[4,5,6]$.

Висновок. Порівняльний аналіз програм медичних шкіл Швейцарії “Анатомія і фізіологія”, "Патофізіологія” і “Патологія” і відповідних вітчизняних свідчить про те, що у викладанні зазначених дисциплін існує низка спільних принципів (невризма, ведуча роль систем життєзабезпечення). Проте досвід, накопичений у нашій країні, заслуговує на особливу увагуз таких напрямків, як:

- більший об' єм і глибина вивчення;

- єдність структури і функцій;

- послідовно вивчаються загальні та окремі питання, що знаходяться в основі нейрогуморальної регуляції функцій організму;

- теоретичні заняття супроводжуються практичними, що забезпечує підготовку студентів до вивчення клінічних дисциплін, що одночасно сприяє формуванню світогляду майбутніх спеціалістів.

Ця думка також підтверджується тим, що багато вітчизняних медичних сестер успішно працюють за кордоном, а більше $15 \%$ випускників в подальшому навчаються у ВН3 III-IV рівнів акредитації. 